\title{
YOUTH IN THE AGE OF HATRED: Religious and Ethnic Factors Within the Islamic Senior High School Students' Reception Toward Hate Narratives
}

\author{
Ahmad Aminuddin \\ Center for Religious and Cross-cultural Studies \\ Email: aminuddin.hamid7@gmail.com \\ M. Iqbal Ahnaf \\ Center for Religious and Cross-cultural Studies \\ Email: iqbalahnaf@gmail.com
}

\begin{abstract}
The rise of hate narratives along with the new model of communication through the internet has become a new challenge for people in this digital era, especially for youth, the $Z$ generation. This generation, in fact, has an intimacy with the internet. It means that they have more possibility for the influence of hate narratives. This study is aimed exploring the influential factors on $Z$ generation reception to the hate narratives on the internet. Specifically, it proposes to recognize the influential factors on the reception of the students of Madrasah Aliyah Negri (MAN) or State Islamic Senior High School of Tuban (MAN Tuban), East Java. This work is based on two hate narrative issues of Suku, Agama, Ras dan Antargolongan (SARA) or religious, ethnic and intergroup diversity backgrounds, including those of anti Christianity and those anti Shiite. This work concludes that the influential factors to the students' reception toward hate narratives come from two categories. First, students are to be the audience of their social systems and backgrounds. The involvement of the students in fundamentalist Muslim groups, in fact, has led them to have exclusive views in seeing others and to feel always under intergroup contestation. Second, the role of the characters of the narratives that influence student's thought is very important to count. It includes the legitimization through emotion which specifically presents fear and feeling threatened. Those characters have further triggered the students' empathy to do something beneficial for the sake of the in-group (altruism). In addition, the characters of the narratives have the figures behind them that have influenced students to immediately believe in the narratives they offer only through seeing their profiles on the internet showing their expertise.
\end{abstract}

Keyword: hate, narratives, youth, reception, influential, factors, Tuban.

\section{INTRODUCTION}

Hate narratives have increasingly become a problem faced by the human 
society which does not only relate to an individual or a group but also affects the stability of human population. Generally, hate narratives contain hatred and instigation leading to the violence which targets others. In the Indonesian context, the impact of hate narratives is more risky because the social condition is diverse. It gradually raises enmity among people and traps them into the condition which is full of hatred nuance. Moreover, when the emergence of hate narratives is provided by groups of people developing the legitimacy of violence and leading the audience to blame others as the enemy. Mostly, common issues used in hate narratives in Indonesia is about religious and ethnicity.

The religious and ethnic diversity often known in the acronym of SARA is a frequent subject of hate narratives. How the hate narrative led to activate violence is illustrated in the riot in Tanjung Balai in 2016. The hate narrative targeted Meiliana (41), a Chinese woman from Tanjung Balai, who raised a concern regarding the volume of Adzan from the loudspeaker system. Yet, mosque leaders felt not comfortable with her concern and regarded it as an offence from the minority. Finally, the emergence of riot coincided with the spreading of hate narratives and it also ignited many people's emotion. Consequently some worshipping houses (vihara) were burned by the mass (Amelia, 2016). Meanwhile, Meiliana further was jailed for two years with the accusation of religious blasphemy.

In the Indonesian context, the high number of the internet users has led people to become susceptible for its negative impacts. According to the Minister of Information of Indonesia, the numbers of the internet users in 2014 are around 82 million people. It puts Indonesia in the $8^{\text {th }}$ ranking as highest countries of internet users. They are $80 \%$ of youth, specifically between 15 until 19 years old. Whereas, the Facebook users of Indonesia ranked in the 4th position (Kominfo. 2014). The data shows that youth is in the highest position as the internet users. However, the use of the internet brings them to choose between positive and negative interest. It is possible to lead them in a dangerous threat when the internet is misused. It is also in reference to the PPIM survey in 2017 concerning on Gen $\mathrm{Z}$ students' attitude and behaviour to the diversity. The research shows that in terms of attitude, $58.5 \%$ of students tend to have radical and intolerance religious view, while in terms of behaviour, $74,2 \%$ of students have moderate behaviour (Saputra. 2018: 6). The research also concludes that students who access the internet to study religious knowledge become more intolerant and radical. In fact, this survey found that for them the internet becomes the primary source (50.89\%) to study religious knowledge (2018:7).

The earlier explanation indicates that youth are vulnerable for the influence of 
hate narratives. However, the high possibility for the exposure of hate narratives is rare to be learned. Specifically on how the youth receive it; what kind of hate narratives' character which influence among youth; and what types of youth are most likely affected by hate narratives. Those questions further show the importance of doing this research considering that there were many studies under its subject but the specific studies focusing on the discussion of factors behind the youth reception to hate narratives are still small in number. This study examines the students' reception based on the enemy image reception concept which is taken from several kinds of literature such as from Dovidio and Reyes. In terms of the subject of the research, this study then focuses on senior high school youth age, specifically, examining reception of the students at MAN Tuban. The work shows how hate narratives have reached youth regardless of their urban-rural boundaries. Although Tuban is a small town, access to the online hate propagation has been possible and easy. Moreover, this study highlights what factors are essential on hate narrative reception within those students. The students were asked to respond the selected hate narratives from the internet which discuss about anti-Christian and Shiite. Those two narratives were taken from a website namely "Voice of Al Islam" (VOA Islam) which is indicated having an affiliation to the fundamental radical Muslim group. In addition, this study merely focuses on analyzing the students' responses who agree with the hate narratives. The narratives used in this study are presented below.

\section{THE RECEPTION FACTORS TOWARD HATE NARRATIVES}

According to a number of social psychological theories, people with specific psychological and social characteristics are more likely to be influenced by the enemy image of hate narratives. These characteristics include authoritarian background or personality, the content of the narratives, social system context (the intergroup competition and stress). First, the authoritarian background or personality in which it urges inferiority and superiority belongs to themselves and in-group and having a perspective to portray the social phenomenon only into two categories; black-and-white terms. On the other hand, the other/ out-group is identified as disdainful and appropriate to be underestimated (Dovidio et. al. 2010: 13). The authoritarian personality in many cases was rooted from the childhood of individual memory, moreover, the one who has under punitive childhood nature of parenting. Otherwise, most of nonauthoritarian were born under egalitarian circumstance (2010: 12). Indeed, the punitive model of parenting for the long turn shapes one's paradigm to be authoritarian and further influences on the way they see the world. The authoritarian background may relate to the social dominance orientation 
(SDO) theory in which according to the theory people with SDO tends to defy equality and assert that the social system should be in hierarchically structured. People with a higher degree in SDO are having a possibility to see the world as a competitive jungle (Son Hing \& Zanna. 2010: 167). Furthermore, it becomes even worse when he/she who has authoritarian personality ever experienced stress - which further will be discussed in the different part of this study - in the past because it enacts a view to differentiate other and to reflect with the personal memory which was ever being under oppression.

Second, the content of the narratives is also important, the extent to which the narratives contain symbols or substances that resonate to the experience of the audience. The effective model of approach in grasping the audience is that reverberate to the audience such as the way to speech, style of narration and diction identify them with themselves. Reyes identifies several characteristics of the message content which often influence the audience including the legitimization through audiences' emotion (Reyes. 2011: 788), predicting future occurrence (2011: 793), lead the audiences' to think rationally to take decision (2011: 786; McDonald, 2008: 65), voice of expertise (2011: 786), and altruism, the author attempts to attract the sympathy of the audience to accept the proposed meaning then to act as if it is advantageous for many people (2011: 801; Gobbles, 1945; Doob. 1950: 435). The famous aphorism also says that lies, when repeated, could be a truth as well.

Third, social system also influence of hate narratives. A certain context of social system is able to shape individual characters and mindset in seeing the world. As a social being, human in the social life generally needs to associate to the group based on such categories and later identifies themselves to which they affiliate as identity. The cause of this phenomenon is the appearance of many group identities in which certain groups for some instances come into the competition for certain goals. When two groups have a similar goal and both are very ambitious, it provides the possibility for competition model through expanding even dominating others that it is assumed as the only way to survive. Precisely, it happens if the goal can only able attained by a single group. Over time, the competitive effort transforms to be enmity between both (Esses. et. al. 2010: 230). Moreover, the competition then gradually becomes worse since the goal is the kind of limited resources (Yzerbyt. 2010: 148).

However, intergroup contestation also leads in creating prejudice and discrimination for each group but on the other side, it can reduce in-group biases (Dovidio et al. 2010: 6). In some cases, feeling under intergroup competition circumstance, such as, caused by social inequality among groups may become an issue motivating people to struggle for the group interest. 
Regardless of whether inequality does exist or merely used as a tool of propaganda. This discourse is mostly related to the dominant, major-group vice versa the inferior, minor-group. Inequality may affect the people's perspective in responding to the occurrence which is experienced in his/her nature. The group which identifies themselves as the subordinated group tends to position themselves as disadvantaged and shaded by a threat from others. Furthermore, their perception constructs a justification of being discriminated.

Intergroup contestation also influences to construct group members' view when receiving the message about outgroup. The stronger one's identification of an in-group identity, the more misappropriate the one to have empathy against an out-group (Struch and Schwartz. 1989: 366). For example, the American people would have much possibility to believe in the narrative which says that Russians have a nasty attitude and so does otherwise. The main reason for this occurrence is because both nations are on the rivalry, hence each member are mostly portrayed with bad prejudice. This nature, of course, would sharply effects to the group's members in receiving the hate narratives about an out-group, especially, to which attributed as a rival. From the individual level, people experiencing stress tends to react aggressively as caused by having fear toward the enemy (outgroup), despite his effort of self-defence. From the psychological perspective, no one is totally free from the paranoid because it is kind of natural aptness belongs to human that it instinctively rises under stressful condition.

Fear to any peculiar thing on human mind exists because biologically they identify themselves with the people whom familiar. In seeing the peculiar, people tend to make clear-cut boundaries to differentiate with others. Indeed, this kind of people will be more comfortable with the familiar (in group) figure otherwise. On the other hand, under stress condition, people become tighter in holding on their identity whether nationality, religious and so forth which further is strongly ingrained with the self (Post. 1999: 339). Thus, stress obviously is also included as one of the influential factors; whether one receives (agree with) hate narratives or rejects. Of course, people who experience stress become easier to receive hate narratives about out-group.

\section{SOCIAL CONTEXT AND STUDENT'S PERSPECTIVE IN SEEING OTHERS}

In reference to the reception theory, this study found that the most influential factor on the students of MAN Tuban is their involvement in the fundamentalist group. This gradually shapes the students' personality to be an authoritarian character. Specifically, authoritarian refers to the Social 
Dominant Orientation (SDO) concept in which people with SDO tend to see others within inferiority. In contradiction, they see themselves or the ingroup as superior. The involvement is not related to the Islamic group that one student or their family affiliate. Instead, this comes from the friendship relation, where and whom they study Islamic teaching. One student may affiliate to moderate Islamic organizations like Nahdlatul Ulama (NU) and Muhammadiyah, but since they were engaged in fundamentalist groups' activities, they mostly received the hate narratives. The students following the fundamentalist' religious sermon are more vulnerable to be contaminated by hate narratives. For instance, UA (17), a student with Muhammadiyah family background, in responding to the hateful narratives confidently judged that all mentioned groups on the narratives are jeopardizing. This even emphasizes that although UA's family background affiliates to moderate organization, in fact, he has been heavy contaminated by the fundamentalist. In reference to Esack's view on the fundamentalist, he argues that the basic character of the fundamentalist group is "enmity toward all who reject views as people who have chosen Evil against God." (Esack. 1997: xi). This may relate with Ahnaf's argument that the fundamentalist generally considers under that Muslim is under siege of the enemies of Islam (2006: 15). The enemies here refer to the non-Muslim (infidel) and to the Muslim likewise who assail the fundamentalist' view so-called as liberal Muslim. Furthermore, Ahnaf's explains that the common enemy image is addressed to the Christian and Jews, also the ideologies such as atheism and communist which is categorized as infidel (kafir) ideology (2006: 13).

The different model of involvement with fundamentalist groups is shown from the three female students, SUK, VSN and VF. VSN joined into both WhatsApp groups named CHC (Cahaya Hijrah Community) and "the Great Woman." SUK is only the member of the first one while VF only joined to the second one. Both groups are special for Muslima (women Muslim). The students' involvement in this case only on the virtual media, WhatsApp group community. The member of both groups never organized gathering meeting as Pantura Hijrah. It is because of the members who are spread from many regencies on Indonesia. VSN stated “Group's members are from many places in Indonesia. It is not based on local regency. Meanwhile, for the CHC group, the total number of the member is 255 persons." Likewise, VSN explained that the members of the group usually discuss Islam including fiqh (Islamic jurisprudence) and other discourses. The discussion is set with the mentoring model in which on both groups, there are ustadzah, women religious cleric, who have an important role as the mentor. For instance, they commonly post or share the information about Islam, sometimes also give advice and 
answer when the members question about the specific issue. However, it does not mean that the members are not allowed to do so. They freely share information about Islam and related issues. This is including photos and videos. For instance, VSN ever watched a video posted on The Great Women group about the different way of Shia on practising wudlu (ablution), praying and sujud (bowing down). She urged that comparing with Sunni tradition, indeed Shiite tradition is different from the Sunni's practices. Based on this view, she concluded that Shiite is deviant because they violated the "true" Islamic teaching from the Prophet.

In a similar vein, religious sermon and open-group discussion -including through WhatsApp group application- are the two model programs which are similar to HTI's model for the new member recruitment. According to Ahnaf, in every Indonesian region, HTI members establish similar activities including a public sermon and open group discussion. The second one generally targets and is organized by youth. The main purpose, of course, is to endorse awareness of the necessity for the establishment of an Islamic state (2006: 6). However, the appearance of a messaging application nowadays took the fundamentalist group consideration to extend their influence. This consideration further emerged a new model program like the finding on this study, utilizing WhatsApp group to catch broader audiences with easy access. Generally, the fundamentalists often present a horrifying image of current Islamic condition. They describe as if Islam nowadays is besieged and under contestation with the infidel. This is especially led by the Jews and the Christian who always struggle to battle against Muslim through all aspects of life. The fundamentalist depicted the current battle was transformed into a different model with the previous one. The previous one was the physical battle with sword represented by the crusade, while currently, it is through the non-physical attack (2006: 18). On the other hand, this battle led Muslim into the contestation to fight against the infidel. This includes the spreading of non-Islamic ideologies and gradually making Muslim to leave the Islamic way of life.

The feeling of under contestation with the out-group (intergroup contestation) basically is caused by a feeling of being oppressed and under siege. It furthermore shapes the harmfulness of out-group images as an enemy. This image is going to be worse when the contestation is related to the primary principle of groups such as ideology and nationality. Inter-group contestation in this study took place as one of the essential factors on students' reception to the hate narratives. However, this factor essentially has a close relationship with the first factor because this assumption emerged when they considered 
that students' groups were targeted by others in order to be dominated. Specifically, on anti-Christian narrative, the feeling of under intergroup contestation is shown from VSN's (17) response. She said that generally Christian is an obvious menace but it also depends on the individuals. VSN addressed especially against the Christian who strictly follows Christian tenet as endanger figure. Furthermore, VSN said that she ever listened to religious sermon audio in which the ustadh explained his experience as a converter. She said:

The Christian clearly planned for an intentional attack against Muslim because they purpose to destroy Islam through its conspiracy. I also ever listened to religious sermon audio. This is from an ustadh who is a Muslim convert. He is a Sundanese who previously was a Christian and ever studied in five countries. His family background is Jews and Christian. Yet, he is the only one who decided to convert as Muslim and unfortunately because of his decision, he was abused by his family. Even, he had to divorce his way and leave the children.

VSN points out the abuse experienced by a Christian who converted to Islam from their Christian family. This occurrence is regarded as the evidence of Christian abhorrence on Muslim on the individual level. Accordingly, when an in-group member crosses to become a member of its rival (out-group), this decision is seen as a betrayal. The betrayal exacerbates the tension when the rivalry between two groups has been established for a long period. In line with van Bruinessen argument, the rivalry between Christian and Muslim was in high tension, specifically for the fundamental radical Muslim. He said that the high tension of its contestation is caused by many similarities belong to both. This includes sacred history, like the Semitic prophet, and religious concept. Not less important, for thousand years both have been neighbours who were contesting not only for theological influence but also for political interest (1995: 64-65).

Likewise, the feeling under inter-group contestation in terms of the anti-Shia narrative obviously occurs. In this narrative, Shiite is depicted as inherently dangerous for the Sunni followers, the mainstream Islamic ideology in Indonesia. The existence of the non-mainstream group in many cases, of course, challenges the domination of the mainstream which was well-established. According to van Bruinessen, the non-mainstream group furthermore is legitimated as aberrant and deviant (1992: 18). This is emphasized by the establishment of Indonesian The anti-Shia national alliance (ANNAS Indonesia) which massively propagates to reject Shiite existence. Most of the members are the fundamentalist group 
including a few Sunni followers. In reference to Islamic history, the contestation between Sunni and Shiite was alarmed since the first period of Islamic. Hence, it sharpens the images of both in seeing each other. In accordance, the article on ANNAS Indonesia official website states why the Shiite refusal is necessary and the refusal does not violate Islamic unity. At least, there are ten arguments in legitimating Shiite image as peril which is used for its legitimation. One of those is that the mushroom of Shiite struggle to convert others into Shia in many Muslim countries whereas the others do not aware that they are being targeted for its conspiracy (ANNAS. 2018). This kind of statement implicitly rises tension of the contestation between Sunni and Shiite because Shiite may also view the same toward Sunni, mutual prejudice. In reference to the enemy image concept, it is called mirror imaging (PfSR, 1989: 59) in which both groups are seeing each other with full of curiosity. Additionally, the students who heavily regarded that they are under inter-group contestation, generally, are those who were contaminated by the fundamentalist view. Meanwhile, on the anti-Shia narrative, the reception was not only received by those who were contaminated by the fundamentalist view. The social condition in which Sunni as the wellestablished mainstream group inflamed the harmful image of Shiite likewise.

\section{HATE NARRATIVES WITH CERTAIN CHARACTERS HAVE MORE POWER TO INFLUENCE}

The narrative which contains such legitimations become more powerful to influence audiences' reception. As mentioned in the previous discussion, there are five legitimizations that refer to Reyes concept. Nevertheless, it does not mean that all legitimations always work for all kind of narrative. The audiences also must be a consideration whether all legitimacies work or only some. In this study, there are three legitimations which essentially contributed to the students' reception. Those are the legitimacy though emotion, the voice of expertise (the narrator) and altruism. Those will be discussed in the following paragraph. One of the essential factors on students' reception from the narrative content is legitimization through emotions. Attracting audiences' emotions may trap them to consider something matter for us as the narrator (Reyes: 2011: 785). Furthermore, Reyes also argued:

Emotions are key in the legitimization process because they condition and prepare the audience to receive proposals and courses of actions. Emotions skew the audience toward accepting and supporting the proposal of the social actor, who has triggered the motions in the first place. (1999: 790) 
This shows that gaining audiences' emotion become one most important aspect to gain more attention and also to make audiences agree with what a narrator distributed. In line with Reyes argument, legitimization through emotion on this study became one most important aspect of students' recept. Legitimization through emotions in narrow understanding means that the narrators manipulated audience emotion through arising and binding a similar sense to the audiences. Practically, the narrator builds clear-cut boundaries among the narrator and the audiences as "us," while the targeted group is imaged as "them" (others) with full of evil characters. This is related to the enemy image concept in which "us" and "them" is included in a biased thinking process. It builds a distinction between in-group and out-group. The in-group implies a superiority while the inferiority is addressed to outgroup which commonly is depicted as less human. According to Liddle, the dichotomy on "us" and "the" is one of visible fundamentalist mentality. This includes a defensive process to see others as the enemy and building a sympathetic perspective to see non-Muslim planned to embattle Muslim under Jews command. (Liddle. 1998: 283).

Meanwhile, on the anti-Shia issue, the statement which shows the attempt of manipulating audiences' emotion is the statement of the plan for murdering Sunni ulama. It is even emphasized with Oqbah statement which insulted the previous riot in Sampang, East Java. The narrative drew Oqbah statement "Farid Oqbah argued that the barbarian attack in Arifin Ilham's Az Zikra village was merely a small scale assault from the holy shit Shia." Furthermore, the statement below is cited as an example to show how the audiences' emotion was manipulated. The statement is also from KAB. He said;

Shia diverges the Prophet teaching. principally, it is forbidden. There are much heresy's on their teaching whereas the Prophet clearly stated that kull bid'ah dalälah which means all heresy is a deviant. The model of Shiite's shahada is also different. They have one additional sentence from the origin of the shahada. Hence, they obviously different from and also jeopardize for us.

The argument shows that KAB previously also had a bad stereotype on Shiite. He pertained to Shiite shahada which is different from the Sunni. The shahada sentence on Shiite version according to him includes a witness on Ali bin Abi Thalib, "Ashhad an La Ilaha Illa Allah wa Ashhad anna Muhammad Rasul Allah wa Ashhad anna 'Aliy Waliyy Allah." This witness is the common perception among lay people on Shiite that they have a different model of the shahada. The different model is also on the Shiite praying ritual. For the 
fundamentalist, Shiite's praying ritual is strictly not in line with the Prophet thought. For instance, according to ANNAS, the national alliance in rejecting Shiite, the practice of Shiite's pray contains many heresies. This includes the use of small stone put on the floor and during the bowing, the Shiite forehead must touch it (ANNAS. 2016). The similar perspective between KAB and the fundamentalist proofs that $\mathrm{KAB}$ has contaminated by fundamentalist view. It is rooted in KAB's participation in religious sermons and opengroup discussion. Both agendas frequently discuss Islamic deviant groups, including Shia. Consequently, it is not weird when after reading the narrative, $\mathrm{KAB}$ immediate justified the narrative afterwards because he seemed to find confirmation argument for his view.

The similar model of justification was addressed on anti-Christian narrative. On this narrative, the highlighted issue is the image of Christians as an infidel who has endless enmity against Muslim. One of the clear legitimization through emotion is shown in Ridwan's statement. As the narrator asserted that the Christian always targets Muslim for their evangelical agenda. He said, "The Christian-Muslim relation is going to worse since the Christians always see Muslim as the target of the evangelical mission." The students' affirmation on this narrative which means that the narrator has succeeded in manipulating their emotion is shown from VSN response. She said;

For me, they (the Christians) intentionally attacked Muslim in Papua, because The Christian in principle will destroy Islam conspiratorially... So far, as I know, The Jews indeed will fight against Islam. Yet, if Muslim revenge them, they obviously will be afraid.

From the response, VSN who had a stereotype against Jews and Christian got legitimation from the narrative and then it made her feel in line with the narrator perspective. Thus, she easily received and confirmed the narrative as truth. VSN's argument is in a similar vein with the statement of Shiddiq alJawi, a previous leader of HTI in Yogyakarta. On his personal interview section with Ahnaf, Shiddiq insisted that all non-Muslim are adverse to Muslim and it is going to be worse and affirmatively seen when Muslim are powerless (2006: 12). Moreover, in this case, Muslim in Papua is the minority and they were the victim for this attack. Finally, it antagonized the Christians within its harmful agenda.

On the other hand, legitimization through emotion primarily has a common model. The emotion which is manipulated by the narrator is the emotion of fear. According to Reyes, fear maybe becomes the most powerful emotion in attracting audiences to give responses. This can be operated to manipulate 
people to gain a goal although it imperils for their life (2011: 790). Through providing imperil image on the narratives, the narrators attempted to trigger audiences' (students) fear and make them feel in a dangerous situation. Thus, students' emotion is easier to be manipulated and finally, they agree with the narrative. A fear and threatened feeling, on the other hand, also trigger altruism. When students' felt that they are in danger and it is not only risk of them as individuals, but also against their groups, consequently it raises their sympathy and altruism.

Altruism furthermore becomes another factor in the students' reception which is triggered by manipulating students' emotion and make them feeling under inter-group contestation. In the present psychological literature, altruism is intimately related to empathy (Sesardic, 1999: 463). Apart from the different meaning of altruism in which in some cases are contradicting, the altruism in this study refers to the "altruistic altruism" which means proposing to benefit others. In a similar vein, this is also able understood as the empathy-based altruism which means "help and care born from empathy with another" (De Waal. 2008: 281). On the anti-Shia narrative, the altruism is manifested into sectarian fanaticism, while on anti-Christian, it is embodied on religious sentiment. The first on labels Shiite as the deviant Muslim and the opposite of the "true Muslim" (Sunni followers), while the second one puts Muslim vis a vis Christian as non-believers. On the anti-Shia narrative, the information of Shiite's plan to kill the Sunni ulama is the obvious harm for the students as the followers of mainstream Islamic ideology, Sunni. Moreover, the narrative presents that the target of the murder plan is the ulama. As the religious elite, the ulama for the believers is seen as an important figure, even, they have an eminent position among people on the social system. The discussion for its subject will be examined deeper on the other part of this chapter.

In terms of the content of the narrative, the statement which impels the students' altruism on the anti-Shia issue is obviously drawn on Oqbah's argument. He said "Since they (Shiite) execute their plan and something worse happened to these ulama, Muslims must react! We have to revenge and we finish them all." Through using Muslim term as group identity, Oqbah has raised altruism feeling from the students. The students furthermore felt that they are needed to contribute to the group interest. In addition, the hate narrative on the anti-Shia essentially provides the prediction of future occurrence because Oqbah urged that Shiite plan is valid information. It is drawn on his statement which said that the Shiite have held a meeting in $22^{\text {nd }}$ December 2014 in Ngawi, East Java and the meeting concluded that they have agreed for the plan. Furthermore, the information was propagated by Oqbah as the 
prediction of future occurrence which especially in this narrative becomes the consideration of the students' reception. However, this factor is only worked on this narrative because its content provides a clear statement of prediction whereas the similar statement is absence on the two other narratives.

On the anti-Christian narratives, there are many statements which raised the students' altruism. One of those is shown on Ridwan statement which said:

This is an irony to see the weak response of the Muslim society in Indonesia. That's only a press conference or, at best, demonstration. This occurrence shows that Muslim relation is fragile.

On this statement, Ridwan appeared his thoughtfulness in seeing the Muslims' response for the riot Tolikara in which according to him it shows the fragile Muslim relation. This may the way he attempted to raise the audience empathy and altruism and hopefully, the audience could see in the same perspective as him. As the result, the audiences could agree and then understand the same. In fact, the students agreed with his argument and his call to react. Nevertheless, the students have a different opinion on how they should react to this issue, even though, basically Ridwan urged to revenge through violence within his metaphor "eyes by eyes, teeth by teeth." Some agreed with Ridwan but others suggested to let the government solve this conflict under the legal constitution.

Apart from the statement which impels students' altruism, in Islamic teaching, the altruism is strongly urged by its teaching. In reference to the theological basis, the Muslim brotherhood concept becomes its motivation in which all Muslims are bound on Muslim Brotherhood, "A Muslim is the brother of a Muslim (al Nawawiy. 2010: 100)." Another hadith, narrated by Nu'man ibn Bashir, even emphasizes that the Brotherhood is portrayed with the metaphoric image of a body entity as below:

Allah's Apostle said, "You see the believers as regards their being merciful among themselves and showing love among themselves and being kind, resembling one body, so that, if any part of the body is not well then the whole body shares the sleeplessness (insomnia) and fever with it (al Bukhariy no. 40).

The hadith clearly urges how Muslims are strongly bound under the brotherhood relation. The boundary further arises an empathy among Muslims, moreover, through the analogy of one body entity in which when the particular limb is hurt, thus the whole will feel the pain likewise. Accordingly, another hadith which is narrated by Abu Musa depicts the relationships among the believers (Muslim) is like one building in which each different 
parts enforce each other (al Bukhariy, the number of hadith: 626). This logic shows that explicitly a Muslim is deemed to maintain their entity and to bother about the other Muslims. If the other Muslim, as the brother and single entity, is disturbed, moreover, by the non-believers, thus the other Muslims feel necessary to give help in the name of Muslim brotherhood concept. Besides, the Shiite who is seen as deviant in this case group is excluded from students' understanding as Muslim. Consequently, Shiite is excluded likewise from the brotherhood relation among Sunni followers as mainstream Muslim. On the other hand, this brotherhood concept, unfortunately, is often misled by the fundamentalist group in which it seems only prioritize the religiosity from symbol and appearance. For instance, they urge to call another Muslim with akhiy, meaning my brother, while for the Muslima with ukhtiy, meaning my sister. The fundamentalist implicitly often misuse this brotherhood concept to emphasize the Muslim single and global civilization (ummah) concept. The main purpose of its misapplication is to gain wider mass for demanding the caliphate.

Apart from the altruism which is strengthened by the theological basis, the figure of the narrator must be pointed out. The figure of the narrator as an expert becomes the consideration for the students in receiving hate narratives. In this case, on the anti-Christian and the anti-Shia narratives, the figure of the expert is obviously provided. Especially on the anti-Christian issue, the expertise is represented by Kyai Cholil Ridwan. He is one of MUI leader at the national level. His position as Kyai is heavy considered by the students thus it influences their reception. Kyai is a Javanese term which in this discussion means as a predicate for the Islamic religious cleric. This term has another meaning including a predicate addressed to the local district leader under the Javanese kingdom era, a name of an object which has magic power i.e. gamelan. Meanwhile, ustadh is cited from an Arabic word which literally means "the teacher man." In the Indonesian context, there has been a shifting paradigm in understanding this term. ustadh is still labelled for a teacher man but it identically addressed for the religious teacher. However, kyai generally has higher social and religious position than an ustadh. The second one only refers to the figure or Islamic teacher or preacher while the first one has a broader role including a teacher, preacher and also leader for the society. Nevertheless, every single person who is entitled as kyai or ustadh commonly gain high social level on society. They are seen as an important figure and indeed respected for their words. The consideration for the importance of both kyai and ustadh figures as the narrator is shown from SPA. She said on Christian and the anti-Shia issue: 
For this information, I agree with kyai Cholil because he is a kyai moreover he also the leader of MUI at the national level. Of course, he has deep considered the information before he shared it to the public.... For the Shiite's plan, I also believe because the spokesperson is an ustadh, moreover, it is delivered on a public religious sermon.

The statement shows that SPA obviously considered the narrator figure in which in this case is the religious elite, both kyai and ustadh. SPA obeyed with the religious elite said, even she could believe in the narrative only because of seeing their figure. This phenomenon in the Indonesian context is not a weird thing. The figure of religious elite has great social class and position among society. Especially, kyai is seen as a charismatic figure who has power and authority not only in terms of religious discourse but also in a social system. In other words, kyai is one of a social elite figure in terms of religious field. The wide and deep understanding of Islamic knowledge is the main factors that make the social system put them into elite category (Faridl. 2007: 239). According to Kellen, an elite has the role as a determinant and social object at once on three conditions. First, it has authority and power in taking the decision. Second, as the proponent for a moral system. Third, it has a high position in society and regarded as a successful one (1995: 213). As a religious elite, in one social system which put religious as the basic values, kyai obviously is put in the high social class. In the Indonesian context, based on PEW research centre survey (2015), Indonesia is ranked in the third position as the countries which see religion as important in social life. Thus, it emphasizes the high position of kyai among society.

In reference to the theological basis, the high level of a religious leader on the social system is caused by the view that they are the Prophet's inheritor. This predicate is based on the hadith which states "Indeed, the Ulama are the inheritors of the prophets..." (al Tirmidhi. 2681)." Another hadith also depicts the importance of ulama figure for the religious believers. The hadith is mentioned below:

Verily, Allah does not take away knowledge by snatching it from the people, but He takes it away by taking away (the lives of) the religious scholars till none of the scholars remains alive... (al Bukhariy. No. 100)

Both hadiths explain the importance and high position of ulama (kyai) among Muslim society. The label as Prophet Inheritor may shape people construction in seeing their figure as the manifestation of prophet image. In Abrahamic religious concept, the prophets or messengers are known individuals who 
bring salvation from the god to human being through the prophecy. They are also depicted as the holy figure who mediates the relation between human being and the creator. Then, since the kyai/ulama is understood as the Prophet inheritor, thus it implicitly describes that they are also the image of God's guidance in the lower level than Prophet. It is also strengthened by the legitimation that the ulama is the representation of God's knowledge and He will take it away only by taking away the ulama's life. Finally, this logic shows that the narrator figures, especially on the anti-Christian and the antiShia narrative, is matter and truly contributed to the students' reception. The figure of the narrator, in this case, surely becomes one of the essential factors on students' reception especially on the anti-Christian and the anti-Shia narratives. At least, it is caused by two perspectives. First, the figure of religious leaders is a charismatic and an expert within their wide and deep knowledge of Islamic discourse. Second, the figure of a religious leader, likewise, is seen as an elite in the social system who have power and authority. In addition, the theological basis which strengthens their position as Prophet Inheritor, thus students can totally believe in the narrative only through seeing their figure within its image.

\section{THEORETICAL REFLECTION}

The work shows that the essential factors on the students' reception are not only caused by a single discourse. The main issue comes from numerous factors either from the students as the audience within their social context or from the character of narratives. In fact, the students' involvement in the fundamentalist group such as religious sermon and open-group discussion becomes the most influential factors. It clearly led them to have an authoritarian personality, meaning to construct their view in seeing others into a strict dichotomy between true and false. The true is portrayed as the manifestation of God image while the false represents evil desire. Those students view Islam as a sole true way, whereas other religions, including the non-Islamic ideology such as communism, are seen as an absolute mistake. This distinction furthermore impelled the feeling of under inter-group contestation between both parties, true and false, which impacted on their perspective. The students see the outgroups not only as a rival but also as the enemy which always harmful to the in-group.

In addition, this study considers the character of the narratives within its contribution to the students' reception. Specifically, by presenting the bad and harmful image of the targeted group, the narrator succeeded in manipulating the students' emotion (legitimization through students' emotion). Accordingly, 
the hate narratives built a hard line between the students and the targeted groups that means those groups are excluded from the understanding as "us." It is clear that the targeted groups were categorized as the out-groups apart from the narrator and the students as in-group. Then, the students would not have any sympathy even see those groups as a dangerous enemy. Meanwhile, the emotion which is legitimated here also means the dread. The narrators might consider that the stereotype against Christian and Shia still exists on Indonesian society perception. Therefore, through presenting the cruel images of the groups, it essentially proposed to affirm and strengthen the stereotype then it exacerbates the students view in seeing the targeted groups. Finally, the appeared dread coincides with the feeling of being threatened and in a dangerous situation.

The dread and feeling under inter-groups contestation consequently imposed an empathy feeling named "altruistic altruism" or the "empathy-based altruism" among the students. The altruism seems like a sequence effect emerged by those two previous factors. Since the students' altruism were triggered, they desired afterwards to react to the issue for the benefit of the communal (in-groups interest), even though the ways they proposed to react are not uniform. Besides, the figure of the narrators as the expert on each narrative is obviously contributed to the students' reception. The figure of religious leaders amplified the narratives' power in guiding the students to believe in the hate narratives. Likewise, the narrators, in this case, are not only seen as the expert on religious knowledge but are considered as elite in their social system. They are accordingly regarded as the trustworthy figure hence the students became easier to believe in the narratives.

\section{CONCLUSION}

The rise of hate narratives for the last decade on the internet obviously has brought some negative impacts, despite the positive, for the young generation considering their intimacy with the internet. Through the internet, hate narratives are able to reach a broader audience from diverse backgrounds including age. Nonetheless, it is not the only motivation for youth to receive hate narratives. In this case, the students of senior Islamic high school age are motivated by numerous factors on their reception; whether it comes from the type of the audience including backgrounds and social context or from the way the hate narratives are presented. The students of MAN Tuban, East Java, receiving the hate narratives are generally those who engaged with the fundamentalist' Muslim group activities like religious sermon and online discussion. Having this engagement, they further become easier to receive hate 
narratives because they were familiar with the presented issue which mostly is the same issue discussed in the fundamentalist religious sermon; providing fear, anxiety under SARA sentiment and provoking them to react. On the other hand, the way the narrative is made, with certain characters mentioned earlier, also contributes to the students' reception. It drives them to think and to reflect on their backgrounds, social systems and experiences besides aiming to manipulate their emotions such as increasing a sense of in-group identity and distinguishing out-groups as dangerous others.

\section{BIBLIOGRAPHY}

Ahnaf, M. I. (2006). The Image of the Other as Enemy; Radical Discourse in Indonesia. Bangkok: Aman Silk Worm Books.

Amelia R, M. (2016, Agustus 2). Ini Motif Ahmad Tulis Status Provokasi Kerusuhan Tanjungbalai. Detik.com. Retrieved from https://news.detik. com/berita/3266902/ini-motif-ahmad-tulis-status-provokasi-kerusuhan-tanjungbalai

ANNAS Indonesia. (2014). Visi dan Misi. Retrieved from http://www.annasindonesia.com/profil/visi-dan-misi-aliansi-nasional-anti-syiah , (2016). Cara Aneh Sholat Orang Syiah. Retrieved from http://www. annasindonesia.com/read/381-cara-aneh-sholat-orang-syiah , (2016). Membahas Syiah Bukan Berarti Memecah Belah. Retrieved from http://www.annasindonesia.com/read/1655-membahas-syiah-bukan-berarti-memecah-belah

Bukhoriy (al), M. I. (2018). al Jami` al Sahih al Bukhariy. Vol. 8. Book 73, Number 40. Retrieved from https://www.sahih-bukhari.com/Pages/ results.php , (2018). al Jami` al Sahih al Bukhariy. Vol. 3, Book 43, Number 626. Retrieved from https://www.sahih-bukhari.com/Pages/results.php , (2018). al Jami‘ al Sahih al Bukhariy. Vol. 1, Book 3, Number 100. Retrieved from https://www.sahih-bukhari.com/Pages/results.php

Doob, L. W. (1950). Goebbels' principles of propaganda. Public Opinion Quarterly, 14 (3), pp. 419-442.

Dovidio, J.F., Hewstone, M., Glick, P. and Esses, V.M., (2010). Prejudice, Stereotyping and Discrimination: Theoretical and Empirical Overview. In Dovidio, J.F. (Ed.). The Sage Handbook of Prejudice, Stereotyping and Discrimination, California: Sage Publication, pp. 3-29. 
Esack, F. (1997). Quran, Liberation and Pluralism: An Islamic Perspective of Interreligious Solidarity against Oppression. Oxford: Oneword.

Esses, V. M., Jackson, L. M., \& Bennett-AbuAyyash, C. (2010). Intergroup competition. In Dovidio, J.F. (Ed.). The Sage Handbook of prejudice, stereotyping and discrimination. California: Sage Publication, pp. 225-240.

Fadani (al), M. Yasin. (1983). T $\}$ abat al Kizbara. Damaskus: Da $>\mathrm{r}$ al Bashi $>$ r.

Faridl, M. (2007). Peran Sosial Politik Kyai di Indonesia. Jurnal Sosioteknologi. 6 (11), pp. 238-243.

Kominfo. (2016). ICT Indicators Infographic Household and Individuals. Jakarta: Author. Retrieved April 2, 2018, from https://web.kominfo.go.id/sites/default/files/20170210-Indikator-TIK-2016-BalitbangSDM-Kominfo.pdf

Liddle, W. (1999). Skripturalisme Media Dakwah: Suatu Bentuk Pemikiran dan Aksi Politik Islam di Indonesia Masa Orde Baru. In Woodward, Mark R (Ed.). Jalan Baru Islam, Memetakan Paradigma Mutakhir Islam Indonesia. Bandung: Mizan, pp. 287.

McDonald, M. (2018). Constructivisms. In Williams, Paul D (Ed.). Security Studies, An Introduction ( $2^{\text {nd }}$ ed.). UK: Routledge, pp. 59-72.

Post, J.M., (1999). The Psychopolitics of Hatred: Commentary On Ervin Staub's Article. Peace and Conflict, 5 (4), pp. 337-344.

PPIM UIN Jakarta \& UNDP Indonesia. (2018). Api Dalam Sekam: Keberagaman Gen Z. Convey Report. Jakarta: PPIM UIN Jakarta, 1 (1).

Psychologists for Social Responsibility. (1989). Dismantling the Mask of Enmity; An Educational Resource Manual on the Psychology of Enemy Images. Washington: Author.

Reyes, A., (2011). Strategies of Legitimization in Political Discourse: From Words to Actions. Discourse \& Society, 22 (6), pp. 781-807.

Sesardic, N. (1999). Altruism. [Review of the book The Evolution and Psychology of Unselfish Behaviour]. The British Journal for the Philosophy of Science, 50 (3) pp. 457-466.

Son Hing, L. S. and Zanna, M. P. (2010). Individual Differences. In Dovidio, J.F. (Ed.). The Sage Handbook of Prejudice, Stereotyping and Discrimination. London: Sage Publication, pp.164-178.

Struch, N. \& Schwartz, S. H. (1989). Intergroup Aggression: Its Predictors and Distinctness from In-Group Bias. Journal of Personality and Social Psy- 
chology, 5 (6), pp. 364-373.

Suara Islam. (2015). Yahudi Kristen Selalu Mengancam. Retrieved from http://www.suara-islam.com/read/index/15282/-Yahudi-Kristen-Selalu-Mengancam

VOA Islam. (2015, February22). Ustadz Farid Oqbah: Syiah Rencanakan Bunuh 100 Ulama Ahlus Sunnah Indonesia, Saya Salah Satunya. Retrieved from http://www.voa-islam.com/read/indonesiana/2015/02/22/35786/ ustadz-farid-oqbah-syiah-rencanakan-bunuh-100-ulama-ahlus-sunnah-indonesia-saya-salah-satunya/\#sthash.mKqoA84w.dpbs

Yzerbyt, V. Y. (2010). Motivational processes. In Dovidio, J.F. (Ed.). The SAGE handbook of prejudice, stereotyping and discrimination. California: Sage Publication, pp. 146-162. 